\title{
Mental health, illness and communal violence in Northern Ireland
}

\author{
John, Lord Alderdice
}

Consultant Psychiatrist in Psychotherapy, Speaker of the Northern Ireland Assembly, and member of the House of Lords

It seems that a population may experience serious prolonged violence but not necessarily exhibit a significant increase in the rate of psychiatric disorders. any psychologically informed books and papers have been published during the past 30 years that have explored different elements of the $N$ orthern Ireland problem. These have ranged from Padraig 0 'Malley's (1990) fascinating examination of the world of the hunger strikers and their families, to a recent socio-psychological study of sectarianism in young children, which was sponsored by the Community Relations Council (Connolly et al, 2002). The latter careful piece of work demonstrated that while children of three years of age are beginning to identify different cultural symbols, there is not much evidence of sectarian attitudes until about five or six years of age. By this time they have not only begun to recognise and identify with partisan symbols, but also to express deeply antagonistic sectarian attitudes. These are not wholly unexpected findings, but the purpose of good research is to enquire whether things are in fact the way one might expect them to be. When it comes to research on clinical psychiatry there is less material but the most interesting and unexpected finding that emerges from the published work of psychiatrists in N orthern Ireland is the limited evidence of any increased violence-related psychiatric illness in the population as a whole.

The pattern of politically motivated violence in $N$ orthern Ireland has not been entirely consistent since 1968, when the 'Troubles' began. During the first couple of years there was extensive civil disturbance, with serious street rioting in urban areas. While these areas remained a major focus throughout subsequent years, the transition to a terro rist campaign, with the bo mbing of military and economic targets as a central component, extended the geographical spread to affected border populations and the commercial centres of provincial towns. Later still assassinations became a major feature, which changed the communal experience of the violence significantly.

In the early 1970s the descent into chaotic lawlessness was dramatic. As Cairns (1994) pointed out, in the 1960s the number of murders in the Greater Belfast area did not reach double figures. (In the period 1960-64 only one murder was reported in the city.) In 1972, however, at the height of the civil disturbances, 467 people died in violent circumstances. Despite this, Alec Lyons (1971), a senior consultant psychiatrist in Belfast, noted no increase in the number of psychiatric hospital admissions and no increase (indeed, a small decrease) in attendances at general practice surgeries at this time. While other work by Lyons tended to suggest an inverse relationship between suicide rates and violent deaths in the community, further enquiry has left this uncertain.

Lyons' interest was followed throughout the 1980s and 1990s by another consultant psychiatrist, Peter Curran, who, with a team of colleagues based in $\mathrm{N}$ orth Belfast, one of the areas of most intense violence, did significant work using the construct of post-traumatic stress disorder (PTSD) to measure the psychological consequences of terrorist violence on individuals (Loughrey et al, 1988; Curran et al, 1990). In two valuable review articles in 1988 and 2001, Curran noted the methodological difficulties in assessing the psychological impact of civil disorder and terrorism (Curran, 1988; C urran \& Miller, 2001). He reviewed various research material that used community surveys, hospital admissions and referral data, psychotropic drug usage, suicide and attempted suicide rates, and data from assessment of the actual victims of violence. $\mathrm{He}$ came to the conclusion that while, clearly, many individuals in $\mathrm{N}$ orthern Ireland have been seriously damaged physically and psychologically it is not easy to know why some have survived their experience better than others, nor why the impact on psychiatric services as a whole has been limited. He showed that, in a number of studies, less than $10 \%$ of referrals and admissions had as their precipitants any vio lence-related issues. It seems that a population may experience serious prolonged violence but not necessarily exhibit a significant increase in the rate of psychiatric disorders.

C airns \& W ilson (1984) took a different approach. Instead of using official health statistics or clinical studies, they conducted community surveys using the $G$ eneral $\mathrm{H}$ ealth $\mathrm{Q}$ uestionnaire and came to the conclusion that while there was evidence of increased stress on the population in a violent area, it accounted for only a minor component of the variability. Cairns (1994) speculated that 'denial' might be an important element in the coping mechanisms of the population, and in his later work reported some evidence that distancing, denial and religious interest and involvement may help to account for how the people of $\mathrm{N}$ orthern Ireland have adapted to living longterm with the threat of vio lence. Certainly it has often been remarked with some puzzlement by psychotherapists in N orthern Ireland how infrequently the Troubles are a focus in their work with patients, except for those who present with direct traumatic experience.

Prior (1993) not only reviewed the clinical and community survey evidence but also addressed the impact of the Troubles on mental health services and found that, 
despite the obvious pressures, the integration of hospital and community work and of health and social services, and a significant per capita increase in public spending on health care, led during this period to worthwhile improvements in mental health services. These are things that may or may not have happened had peace prevailed.

That services have improved and the population as a whole has coped remarkably well does not mean, of course, that those individuals who are seriously affected do not require appropriate help and treatment. D aly (1999) examined the treatment needs of the community generally as well as specific victim groups such as the security forces, children, the bereaved and prisoners. This raises a further but as yet still anecdotal observation. After the much publicised cease-fires there was a substantial, albeit ragged, reduction in terrorist activity; however, many health care professionals would corroborate the remark by Curran \& Miller (2001) that with this reduction in violence there has been some increase in the presentation of victims of the Troubles. 0 ne implication may be that once the curiously 'holding environment' of the Troubles is lifted we may observe a negative as well as a positive 'peace dividend'. Who knows if it may yet be too early to be fully clear about the impact of the past 30 years on the psychological welfare of the people of $\mathrm{N}$ orthern Ireland?
Cairns, E. (1994) Mental health and political violence in N orthern Ireland. A review of research. In Proceedings of the 1994 European Regional Conference of the World Federation for Mental Health. Belfast: Northern Ireland Association for Mental Health.

Cairns, E. \& W ilson, R. (1984) The impact of political violence on mild psychiatric morbidity in Northern Ireland. British Journal of Psychiatry, 145, 631-635.

Connolly, P., Smith, A. \& Kelly, B. (2002) Too Young to Notice? Belfast: Community Relations Council.

Curran, P. S. (1988) Psychiatric aspects of terrorist violence N orthern Ireland 1969-1987. British Journal of Psychiatry, 153, 470-475.

Curran, P. S., Bell, P., Murray, A., et al (1990) Psychological consequences of the Enniskillen bombing. British Journal of Psychiatry, 156, 479-482.

Curran, P. S. \& Miller, P. W. (2001) Psychiatric implications of chronic civilian strife or war: $N$ orthern Ireland. Advances in Psychiatric Treatment, 7, 73-80.

Daly, O. E. (1999) N orthern Ireland. The victims. British Journal of Psychiatry, 175, 201-204.

Loughrey, G. C.. Bell, P., Kee, M., et al (1988) Post-traumatic stress disorder and civil violence in Northern Ireland. British Journal of Psychiatry, 153, 554-560.

Lyons, H. A. (1971) Psychiatric sequelae of the Belfast riots. British Journal of Psychiatry, 118, 265-273.

0 'Malley, P. (1990) Biting at the Grave - The Irish Hunger Strikes and the Politics of Despair. Belfast: Blackstaff Press.

Prior, P. (1993) The 'troubles' and mental health. In Mental Health and Politics in Northern Ireland. Aldershot: Avebury.

\title{
Development of mental health services in Pakistan
}

\section{Malik Hussain Mubbashar}

\author{
Sheikh Sayed Hospital, Lahore, Pakistan
}

\section{Background}

Pakistan is a country comprising four provinces: Punjab, Sind, N orthwest Frontier Province and Baluchistan, in addition to the federally administered tribal areas and the federal capital territory of Islamabad. It is bordered by C hina, Afghanistan, Iran and India. It has a population of 152 million (excluding an estimated 3-4 million Afghan and Bangladeshi immigrants) and an area of $796095 \mathrm{~km}^{2}$.

The per capita gross national product (G N P) is $\$ 483$ and the budget of the Ministry of Health is $5 \%$ of the national budget, or $0.7 \%$ of the G N P (1997 figures). The annual per capita expenditure on health by the Ministry of $\mathrm{H}$ ealth is $\$ 3.5$, compared with the national expenditure of $\$ 31$. The ratios of beds, doctors, dentists and nurses to 10000 population work out at $6.9,6.0,0.25$ and 4.1 , respectively. The mental health budget is $0.4 \%$ of the overall health budget.

From amodest beginning in 1947, when there were only three mental hospitals, at Lahore, Hyderabad and Peshawar, and a psychiatric unit at the M ilitary H ospital in Rawalpindi, psychiatric units were gradually established in all the medical colleges of the country, especially during the 1970s.

\section{Training}

At the undergraduate level, behavioural sciences have been incorporated in the curricula of all the medical schools in Pakistan. An indigenous behavioural sciences teaching module has been develo ped for medical students and a demonstration project of community-oriented medical education with an emphasis on behavioural sciences was established in 1998 in four of the public sector medical colleges in all the provinces of the country.

At the postgraduate level, fellowship (FCSP), MD and diploma courses are available. The College of Physicians and Surgeons Pakistan (CPSP) is the main certifying body for postgraduate training in psychiatry; a four-year training programme leads to a fellowship in psychiatry. This training is carried out at specified institutions under the supervision of certified trainers. The training involves exposure to adult, forensic, child and adolescent, geriatric and liaison psychiatry patients in a graded manner that is monitored by the CPSP through regular reports from the supervisors, trainees and its own inspectors. The trainee has to complete a research project and submit a dissertation during this training period, besides attending workshops (organised by
That services have improved and the population as a whole has coped remarkably well does not mean, of course, that those individuals who are seriously affected do not require appropriate help and treatment.
The annual per capita expenditure on health is $\$ 3.5$, compared with the national expenditure of \$31. The mental health budget is $0.4 \%$ of the overall health budget. 